\title{
Stability of Dry and Liquid Metschnikowia pulcherrima Formulations for Biocontrol Applications against Apple Postharvest Diseases
}

\author{
Andreas Bühlmann ${ }^{1,+}+\mathbb{D}$, Sandrine Kammerecker ${ }^{2,+}$, Laurin Müller ${ }^{2,+}{ }^{\mathbb{D}}$, Maja Hilber-Bodmer ${ }^{2}$, Sarah Perren ${ }^{1,+}$ \\ and Florian M. Freimoser $2, *$ (D) \\ 1 Agroscope, Competence Division Plants and Plant Products, Müller-Thurgau-Strasse 29, \\ 8820 Wädenswil, Switzerland; andreas.buehlmann@agroscope.admin.ch (A.B.); \\ sarah.perren@agroscope.admin.ch (S.P.) \\ 2 Agroscope, Research Division Plant Protection, Müller-Thurgau-Strasse 29, 8820 Wädenswil, Switzerland; \\ sandrine.kammerecker@bluewin.ch (S.K.); laurin.mueller@agroscope.admin.ch (L.M.); \\ maja.hilber-bodmer@agroscope.admin.ch (M.H.-B.) \\ * Correspondence: florian.freimoser@agroscope.admin.ch \\ + All four authors contributed equally.
}

check for updates

Citation: Bühlmann, A.;

Kammerecker, S.; Müller, L.; Hilber-Bodmer, M.; Perren, S.; Freimoser, F.M. Stability of Dry and Liquid Metschnikowia pulcherrima Formulations for Biocontrol Applications against Apple Postharvest Diseases. Horticulturae 2021, 7, 459. https://doi.org/ 10.3390/horticulturae7110459

Academic Editors: Alessandra Di Francesco, Gianfranco Romanazzi and Rosario Torres

Received: 26 August 2021

Accepted: 27 October 2021

Published: 3 November 2021

Publisher's Note: MDPI stays neutral with regard to jurisdictional claims in published maps and institutional affiliations.

Copyright: (c) 2021 by the authors. Licensee MDPI, Basel, Switzerland. This article is an open access article distributed under the terms and conditions of the Creative Commons Attribution (CC BY) license (https:// creativecommons.org/licenses/by/ $4.0 /)$.
Abstract: The yeast Metschnikowia pulcherrima is frequently isolated from environmental samples and has often been reported to exhibit strong antagonistic activity against plant pathogens. In order to assess the potential of this species for its development into a plant protection product, the survival during formulation and storage were quantified and field efficacy was assessed over a period of five years. Freeze dried and liquid M. pulcherrima formulations (i.e., with skim milk powder (SMP), sucrose, glycerol, xanthan, without additives) were prepared and the number of viable cells was quantified during storage at different temperatures. Field trials against apple postharvest diseases (Neofabreae) were performed with different dry formulations. M. pulcherrima proved exceptionally stable for many months and even years. Five years of field trials with the yeast revealed variable effects, but reduced Neofabreae infections of stored apples were observed in some years. M. pulcherrima applications after prior fungicide treatments repeatedly showed an additive effect as compared to the fungicide treatments alone. In summary, M. pulcherrima exhibited highly advantageous storage properties and encouraging activity against apple postharvest rots. Further studies to identify the factors responsible for antagonistic activity in the field and survival during storage are expected to lay the foundation for the future development of a plant protection product.

Keywords: biocontrol; field trial; formulation; Metschnikowia; Neofabraea; postharvest disease; storage; viability

\section{Introduction}

Many yeast species are promising biocontrol agents for the control of plant pathogenic fungi and as alternatives of chemical pesticides [1]. In particular, their undemanding culture requirements, stress resistance, and few biosafety concerns are advantageous properties for applications in agriculture. Metschnikowia pulcherrima is a species belonging to the order Saccharomycetales and frequently isolated from phyllosphere samples worldwide [2,3]. The species is often reported as a strong antagonist of plant pathogenic fungi and another species of the same genus, Metschnikowia fructicola, has been commercialized as a plant protection product [4-8]. Ample research has addressed the role of the red pigment pulcherrimin and iron chelation in the mode of action of this yeast, but a combination of different factors, rather than iron chelation alone, seem to mediate biocontrol activity [2,9]. The species $M$. pulcherrima is also noteworthy for the production of oils and biofuels, its use in wine fermentation, and the exudation of the fragrance molecule 2-phenylethanol [10-13]. 
With respect to an application for plant protection, a stable product that maintains viability and biocontrol activity over long periods of time and is readily biodegradable at the same time is one of the most crucial aspects [14,15]. For biocontrol yeasts, dry formulations, powders or granules, are often used, but liquid formulations have also been produced [16]. The latter are often preferred due to the easier handling and application, lesser concerns about dust formation, and facilitated production [17-19]. Liquid formulations usually contain a buffer that helps maintain cell viability or even the formation of durable cell types, substances that reduce sedimentation, components that reduce water activity, as well as additives that will enhance adherence or establishment in the field [15]. More sophisticated formulations include microencapsulation, Pickering emulsions that are stabilized by insoluble nanoparticles, or microemulsion, a technology that is widely used and exhibits advantageous properties (e.g., ultramicroscopic droplet size, low surface tension, stability, water solubility) for the formulation of pesticides [20-23]. To the best of our knowledge, these technologies have not yet been used to formulate biocontrol yeasts. In contrast, dry formulations usually contain protectants that stabilize the microorganisms during the drying process and later storage [24-26]. Different methods for drying biocontrol microorganisms are being used, from gentle freeze-drying to methods employing hot air (e.g., spray- or fluidized bed-drying), vacuum-drying, or air-drying, but in all cases the actual drying process results in considerable losses of cell viability [24]. Nevertheless, drying is most commonly used to formulate biocontrol yeast; for example, in commercially available, yeast-based products $[27,28]$.

Here, we compared the long-term survival of M. pulcherrima in simple liquid and dry formulations, tested effects on biocontrol activity, and performed field trials against apple postharvest diseases with a freeze-dried test product containing milk powder and sucrose as additives.

\section{Materials and Methods}

\subsection{Strains and Cultivation}

All storage experiments were performed with the M. pulcherrima isolate APC 1.2 (CCOS978; Culture Collection of Switzerland) [4]. This yeast was isolated from apple flowers and assigned the UNITE species hypothesis SH180747.07FU, corresponding to M. pulcherrima (Pitt \& M.W. Mill.) [2,29]. Additional yeasts that were used for in vitro competition assays were Aureobasidium pullulans (NBB 7.2.1; CCOS1008), Candida subhashii (FGA 2.2; CCOS1004), Hanseniaspora sp. (APC 1.2; CCOS984), Pichia kluyveri (APC 11.10B; CCOS982), and Wickerhamomyces anomalus (SCH 5.6). All isolates were obtained from Swiss agricultural samples and used in previous studies [2,4,30,31]. For competition assays, an isolate of Gibberella fujikuroi (BC 8.14, CCOS1020, SH213620.07FU), obtained from an agricultural soil sample, was used as a model. The same isolate has been used in the past to characterize biocontrol activity of different yeasts and was inhibited similarly to other plant pathogens [4]. Spores of the storage pathogen Neofabraea vagabunda were isolated from symptomatic apples of the cultivar Golden Delicious and species identity was confirmed using qPCR as published previously [32]. All fungi were cultivated on potato dextrose agar (PDA; Becton, Dickinson and Company, Le Pont de Claix, France) at $22{ }^{\circ} \mathrm{C}$ and transferred to fresh plates weekly. Growth experiments were performed in yeast nitrogen base medium (YNB, without amino acids, but with ammonium sulfate; supplemented with a complete supplement mix (CSM); Formedium ${ }^{\mathrm{TM}}$, Norfolk, United Kingdom) and with different carbon sources (see section on growth assays in YNB supplemented with xanthan).

\subsection{Dry Formulation of M. pulcherrima}

The dry M. pulcherrima formulations were ordered from and produced by Bio-Protect $\mathrm{GmbH}$ (Konstanz, Germany). For each test preparation, single fermenter runs (no replicates) were performed according to a standard protocol. Precultures were grown in $100 \mathrm{~mL}$ Erlenmeyer flasks $\left(26-27^{\circ} \mathrm{C}, 200 \mathrm{rpm}\right)$ and used to inoculate a Labfors bioreactor (Infors HT, Bottmingen-Basel, Switzerland; 6.8-8.2 L starting volume in the different fermenter runs). 
The fermenter was set to $\mathrm{pH} 5.5 \pm 0.5,25 \pm 1{ }^{\circ} \mathrm{C}, \mathrm{pO}_{2} 50 \%$, drive $300 \pm 200 \mathrm{~min}^{-1}$. The culture medium consisted of $10 \%$ sucrose, $1 \%$ Hakaphos ${ }^{\circledR}$ Grün (NPK fertilizer containing magnesium 20-5-10(+2), boron, iron, copper, manganese, molybdenum, and zinc; COMPO EXPERT GmbH, Münster, Germany), and $0.4 \%$ yeast extract. As an anti-foaming agent, rapeseed oil was used. After a run time of 18-29 h, M. pulcherrima cells were harvested by centrifugation $\left(20 \mathrm{~min}, 8^{\circ} \mathrm{C}, 4000 \mathrm{rpm}\right.$ ). The resulting yeast cell suspension was formulated with $10 \%$ skim milk powder (SMP) and 10\% sucrose (or with either or none of these two components). The different formulations were frozen at $-20{ }^{\circ} \mathrm{C}(2-11 \mathrm{~d})$ and then freeze dried (2-3 d). The dried cells were powdered and a quality check was performed (assessment of bacterial contamination by plating on nutrient broth/sucrose agar). The number of viable cells was determined at all stages along the production pathway by dilution, plating, and counting M. pulcherrima colonies (see below). All dry formulations were stored at $4{ }^{\circ} \mathrm{C}$. To assess stability, the first batch of the dry M. pulcherrima formulation was also stored at $22{ }^{\circ} \mathrm{C}$.

\subsection{Liquid Formulation of M. pulcherrima}

M. pulcherrima was grown in $20 \mathrm{~mL}$ potato dextrose broth (PDB; Becton, Dickinson and Company, Le Pont de Claix, France) in $50 \mathrm{~mL}$ Erlenmeyer flasks overnight at $22{ }^{\circ} \mathrm{C}$ and $150 \mathrm{rpm}$ in an Ecotron incubator (Infors AG, Bottmingen, Switzerland). Cells were collected by centrifugation in a benchtop centrifuge (2-3 min, maximum speed, in $2 \mathrm{~mL}$ tubes; or $5 \mathrm{~min}$ at $3500 \mathrm{rpm}$ in $15 \mathrm{~mL}$ falcon tubes). Cell pellets were washed with sterile desalted water, resuspended in sterile desalted water, and the $\mathrm{OD}_{600}$ was determined. The calculated amount of cell suspension required for an $\mathrm{OD}_{600}$ of 0.1 was added to the different formulations. These formulations consisted of 20\% glycerol (Carl Roth GmbH + Co. KG, Karlsruhe, Germany), xanthan (5 g/L; Sigma-Aldrich Chemie GmbH (Merck), Buchs, Switzerland), a mixture of $20 \%$ glycerol and $5 \mathrm{~g} / \mathrm{L}$ xanthan, and water. Stock solutions of xanthan $(10 \mathrm{~g} / \mathrm{L})$ and glycerol (40\%) were prepared in desalted water, autoclaved, and mixed or diluted accordingly before use. Samples were stored at $22{ }^{\circ} \mathrm{C}$ or $30^{\circ} \mathrm{C}$ to observe temperature-dependent effects on long-term cell viability.

\subsection{CFU Determination}

The cell viability of dry M. pulcherrima formulations was assessed by dissolving $0.1 \mathrm{~g}$ of the dry powders in sterile water. The suspension was gently shaken for 30 min. Five consecutive 10-fold dilutions were made with sterile water and 10 to $50 \mu \mathrm{L}$ was plated on PDA. Plates were incubated at $22{ }^{\circ} \mathrm{C}$ for two days before $M$. pulcherrima colonies were counted. The dilution resulting in a total number of 100 to 200 colonies per plate was counted. The original concentration of $\mathrm{CFU} / \mathrm{g}$ powder was calculated by multiplying with the total dilution and by considering the volume that was plated. Each sample was plated and counted four times.

For determination of the viability of the liquid M. pulcherrima formulations, aliquots of $10 \mu \mathrm{L}$ were taken from each sample and diluted 100-fold with sterile desalted water. At later time points, when the samples containing xanthan exhibited a multiplication of cells, samples were diluted 1000- or 2000-fold. As the cell viability decreased, the dilutions were adjusted to obtain suitable amounts of colonies for counting. An amount of $20 \mu \mathrm{L}$ of the diluted samples was plated on big PDA plates ( $94 \mathrm{~mm}$ diameter) and colonies were counted after incubation at $22^{\circ} \mathrm{C}$ for $2-3$ days. Samples showing contamination were not evaluated further.

\subsection{Competition Assay with Stored Cells}

Cells stored in dry formulation were dissolved and diluted as explained above (see above) and plated at a density of 30-50 CFU/plate. Cells from liquid formulations which had been stored at $22{ }^{\circ} \mathrm{C}$ for 100 days were diluted to different densities to obtain a similar number of colonies on each plate and resulted in $1.66^{*} \times 10^{4}$ to $2.35^{*} \times 10^{4} \mathrm{CFU} / \mathrm{mL}$. A freshly grown overnight culture was included as a reference. The cell densities were 
adjusted to the sample with the lowest measured viable cell count, counted four days before the experiment for the stored cells. For the fresh culture, the expected viable cell count was derived from previous experiments. Sample amounts of $10 \mu \mathrm{L}$ were plated on small PDA plates (60 mm diameter). G. fujikuroi was adjusted to $\mathrm{OD}_{600}=0.1$ and $5 \mu \mathrm{L}$ was added to the center of the plate. Plates were incubated at $22{ }^{\circ} \mathrm{C}$ for $4-6$ days. The growth area of G. fujikuroi was measured with a Planimeter (Planix 5.6, Tamaya Technics Inc., Tokyo, Japan). The growth area of G. fujikuroi growing on PDA without M. pulcherrima served as the control and results were normalized to this value. Each treatment was replicated three to four times for each assay.

\subsection{Growth Assays in YNB Supplemented with Xanthan}

M. pulcherrima cultivation and collection of cells were performed as described above. YNB was supplemented with glucose $(5 \mathrm{~g} / \mathrm{L}$, Carl Roth $\mathrm{GmbH}+\mathrm{Co}$. KG, Karlsruhe, Germany) or xanthan (5 g/L, from Sigma-Aldrich Chemie GmbH (Merck), Buchs, Switzerland). A culture without a carbon source served as the control. The respective media were inoculated with $M$. pulcherrima to an $\mathrm{OD}_{600}$ of 0.1 , with three replicates for each medium. Cells were cultivated at $28^{\circ} \mathrm{C}$ while shaking at $200 \mathrm{rpm}$ in an Ecotron incubator (Infors AG, Bottmingen, Switzerland). Growth was assessed by cell counting. An amount of $100 \mu \mathrm{L}$ of culture was added to flat bottom Greiner 96-well plates (Greiner Bio-One GmbH, Kremsmünster, Austria) and measured without a lid in a Spark ${ }^{\circledR}$ multimode plate reader (Tecan Group Ltd., Männedorf, Switzerland). For cell counting, $12 \mu \mathrm{L}$ (samples containing xanthan) or $10 \mu \mathrm{L}$ of culture were added to a Cell Chip ${ }^{\mathrm{TM}}$ (Tecan Group Ltd., Männedorf, Switzerland) and cells were counted with the SparkControl ${ }^{\mathrm{TM}}$ cell counting app on the TECAN Spark reader (settings: cell size: 4-30 $\mu \mathrm{m}$, eight pictures). Total cell count outputs of three samples were used for further analysis.

\subsection{In Situ Competition Assays on Apple Fruit}

Overnight yeast cultures, grown as described above, were diluted to $1 \times 10^{7} \mathrm{CFU} / \mathrm{mL}$. $N$. vagabunda spores isolated from symptomatic apples were diluted to $1 \times 10^{5}$ spores $/ \mathrm{mL}$. Apples were surface sterilized in $0.1 \% \mathrm{NaOCl}$ for $10 \mathrm{~s}$ and rinsed with sterile desalted water. Each apple was wounded five times along the equator of the fruit with a sterilized wounding device of a $5 \mathrm{~mm}$ diameter. For each apple, two wounds were inoculated with $15 \mu \mathrm{L}$ of biocontrol yeast and, following a waiting period of $3 \mathrm{~h}$ or $24 \mathrm{~h}$, with $15 \mu \mathrm{L}$ of N. vagabunda. Two wounds served as the positive control and were only inoculated with $N$. vagabunda. One wound of each apple was a negative control that was only treated with sterile desalted water. Ten apples were used for each yeast species. Inoculated apples were stored for 21 days at $20{ }^{\circ} \mathrm{C}$ and $60 \%$ r.H. and lesion diameter was measured. The average lesion diameter with and without biocontrol yeast was determined for each apple. The values of the 10 apples were used for statistics and to calculate the reduction of the lesion diameter by the different biocontrol yeasts. The whole trial was performed twice.

\subsection{Field Trial, Harvest, Storage and Evaluation}

Apple trees of the cultivar Malus pumila var. Golden Delicious were used for all experiments within this study. Trees were planted in 2009 in a research orchard in Wädenswil, Switzerland $(47.220433,8.666590)$. The altitude of the orchard is $560 \mathrm{~m}$ above sea level, and the average yearly precipitation is $1300 \mathrm{~mm}$. Apple trees were planted in two blocks of eight rows with 20 to 29 trees in each row. The planting distance between the trees was $3.5 \times 1.2 \mathrm{~m}$. The orchard was covered with a hail protection net and pheromone dispensers were installed for disrupting the mating habits of codling moths. Each treatment was carried out in four replicates comprised of 11-15 trees each. The replicates were randomly distributed in the orchard. All trees were treated with the same integrated pest management control (IPC), typically applied by conventional Swiss commercial producers, including 11 sprays of different synthetic fungicides (anilinopyrimidine, trifloxstrobine, and phtalimides) until mid-June. No spraying was applied until the start of the trial at the 
end of July or mid-August (depending on the trial year). The application of fungicides and yeast was adjusted to the tree row volume. Treatments were compared to an untreated control (C) and an integrated pest management control (IPC), including application of Captan (captan) $0.125 \%$ and Flint (trifloxystrobin) $0.015 \%$ (CF), once, 21 days before harvest. M. pulcherrima was applied in concentrations of approximately $10^{10} \mathrm{CFU} / \mathrm{L}$ (except for a trial in 2020, which included a treatment with approximately $10^{11}$ CFU/L) 21, 10-15, and/or 3 days before harvest. In some years, a treatment with the commercially available product BlossomProtect ${ }^{\mathrm{TM}}$, containing $A$. pullulans as the active ingredient, was included for comparison. Apples without visible damage and no signs of disease were harvested at optimal ripeness in mid-September and stored in regular cold storage at $1^{\circ} \mathrm{C}, 95 \%$ r.H., and ambient gas concentrations from mid- October to the end of May. All apples were harvested and stored per treatment, not for each replicate separately. After a simulated shelf-life period of seven days at $20^{\circ} \mathrm{C}$, the percentage of infected fruits was scored visually, assisted by a lab scale grading machine equipped with intelligent sorting (iQS, Greefa, Tricht, The Netherlands). Healthy and diseased apples were weighed and the percentage (of the total weight of each treatment) of diseased apples was calculated.

\subsection{Statistical Analyses}

All statistical analyses were performed in R 4.1.1. Normality and equality of variance were tested using shapiro.Test and leveneTest from the packages stats v3.6.2 and car v3.0-11, respectively. Depending on the outcome, one-way ANOVA with Tukey's multiple comparisons test and Benjamini-Hochberg correction or a two-sided Kruskal-Wallis test with a Dunn multiple comparisons test and Benjamini-Hochberg correction were performed in packages stats v3.6.2 or FSA v0.8.20. Significance was visualized by adding letters to the plots, where different letters denote statistical significant differences.

\section{Results}

\subsection{Freeze-Dried Formulation of M. pulcherrima Retains Cell Viability over Several Months}

In order to obtain homogeneous and standardized test material for field and laboratory assays, M. pulcherrima was grown, formulated, and commercially produced as a dry powder. With two batches of M. pulcherrima powder, produced in 2016 and 2017, we performed storage experiments to assess the long-term survival of dried M. pulcherrima cells.

Dried and formulated (10\% SMP, $10 \%$ sucrose) M. pulcherrima cells remained viable during the first 10 weeks of storage at 4 or $22^{\circ} \mathrm{C}$ (Figure $\left.1 \mathrm{~A}\right)$. During eight months of storage at $4{ }^{\circ} \mathrm{C}$, the number of viable cells in the powder did not decline. Although the viable cell number had significantly declined (as compared to the fresh product) after 29 and 43 months $(p<0.05)$, more than $80 \%$ of the cells were still alive (Figure 1B). This result was similar for the production batches from 2016 and 2017, except that the test product from 2017 had a higher initial cell count (Figure 1B). In contrast, the cells stored at $22{ }^{\circ} \mathrm{C}$ started losing their viability after 10 weeks and, at the 30 -week time point, less than $1 \%$ of the cells were still alive. In order to test how the different formulation components (e.g., SMP and sucrose) affect survival of $M$. pulcherrima cells in the dried product, different formulations were prepared (i.e., without additives, only SMP or sucrose, or both SMP and sucrose). Cell viability measurements of the different formulations suggested a beneficial effect of sucrose and in particular SMP on survival during the freeze-drying procedure (Table 1; Figure 2). While $72.1 \%$ of the cells survived freeze-drying in the complete formulation, only $43.1 \%, 22.6 \%$, and $12.5 \%$ survived if only SMP, only sucrose, or no additive was used in the formulation, respectively. The four different formulations had comparable cell counts per weight $\left(1.8-4.0 \times 10^{10} \mathrm{CFU} / \mathrm{g}\right)$, but the formulations containing SMP, sucrose or both of these components (each at $10 \%$ of the wet weight of the harvested cells) resulted in more freeze-dried product and thus in a higher total number of active cells (Table 1). The shelf life of the M. pulcherrima powder containing the different formulation compounds was tested as for the complete formulation by plating cells at different time points. Interestingly, the beneficial effect of the formulation additives was lost within the first seven months 
of storage at $4{ }^{\circ} \mathrm{C}$, after which all four formulations contained between $1.7 \times 10^{10}$ and $2.4 \times 10^{10} \mathrm{CFU} / \mathrm{g}$. In addition, after 10 months of storage, all formulations resulted in similar CFU numbers; between $2.0 \times 10^{10}$ and $2.5 \times 10^{10} \mathrm{CFU} / \mathrm{g}$ for $M$. pulcherrima without additive and the complete formulation, respectively (Figure 2).
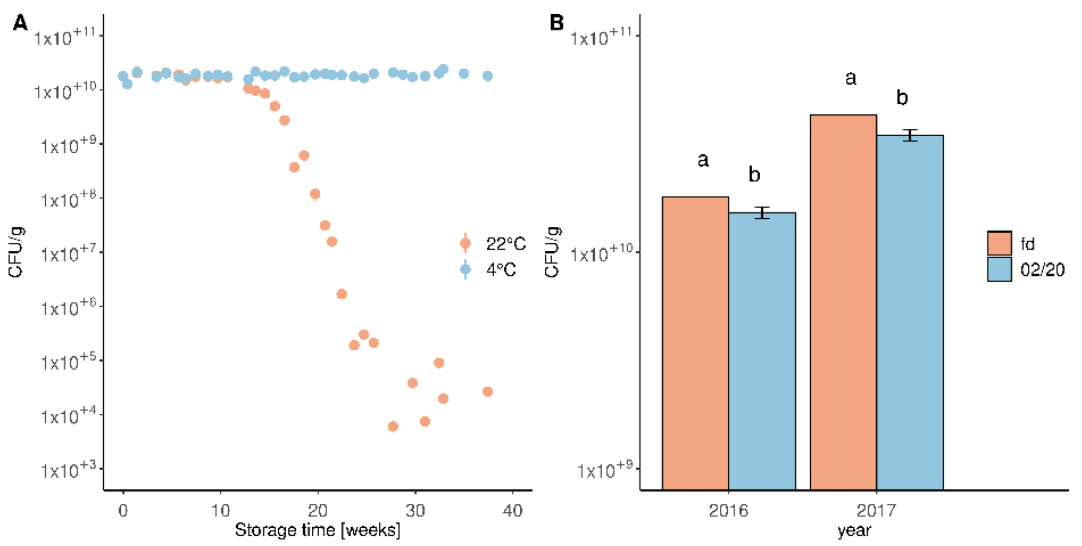

Figure 1. Freeze-dried M. pulcherrima formulations stored at $4{ }^{\circ} \mathrm{C}$ are stable over several years. (A) Freeze-dried cells, formulated with a combination of $10 \%$ skim milk powder (SMP) and $10 \%$ sucrose, were stored at $4{ }^{\circ} \mathrm{C}(\bullet)$ or $22{ }^{\circ} \mathrm{C}(\bullet)$. Cell viability was determined by suspending cells in water, diluting, and plating on PDA. Colonies were counted after two days of incubation at $22{ }^{\circ} \mathrm{C}$. (B) Freeze-dried cells were produced in 2016 and 2017 (formulated with 10\% SMP and 10\% sucrose) and stored at $4{ }^{\circ} \mathrm{C}$. The CFU/g was determined directly after freeze-drying (fd) and in February $2020(02 / 20)$. The difference in the initial CFU counts after freeze-drying were due to production differences. Numbers are represented in a logarithmic scale. Each sample was plated four times and the averages and standard errors are shown. Letters indicate statistical significance determined by one-way ANOVA with Tukey's multiple comparisons test and Benjamini-Hochberg correction $(p<0.05)$.

Table 1. Yield and survival of different, commercially produced M. pulcherrima dry formulations during the freeze-drying procedure from single fermenter rounds. For all formulations, $320 \mathrm{~g}$ of yeast suspension were mixed with the different formulating compounds.

\begin{tabular}{ccccc}
\hline Formulation & CFU/g & Yield (g) & Survival (\%) & Total Viable Cells \\
\hline No additive & $2.1 \times 10^{10}$ & 30.3 & 12.5 & $6.3 \times 10^{11}$ \\
$10 \%$ sucrose & $1.8 \times 10^{10}$ & 61.9 & 22.6 & $1.1 \times 10^{12}$ \\
$10 \%$ SMP & $3.5 \times 10^{10}$ & 60.8 & 43.1 & $2.1 \times 10^{12}$ \\
$10 \%$ sucrose $+10 \%$ SMP & $4.0 \times 10^{10}$ & 90.6 & 72.1 & $3.6 \times 10^{12}$ \\
\hline
\end{tabular}

These experiments indicated a stable and long shelf life of dried M. pulcherrima cells if kept at $4{ }^{\circ} \mathrm{C}$. While SMP and sucrose improved the survival of M. pulcherrima cells during freeze-drying, later storage at $4{ }^{\circ} \mathrm{C}$ was not affected by these additives.

\subsection{Liquid Formulations of M. pulcherrima Remain Viable for Several Months}

Although dry formulations are mostly used for the preparation of biocontrol yeasts, liquid formulations are often preferred [30]. Since M. pulcherrima seemed to tolerate long-term storage in dry formulations well, its survival in water, glycerol, and xanthan formulations was tested.

Regular plating and colony counting revealed that M. pulcherrima cells remained viable for several months in all liquid formulations and during storage at $22^{\circ} \mathrm{C}$ (Figure $3 \mathrm{~A}$ ). The highest $\mathrm{CFU}$ counts were obtained for the formulation containing $5 \mathrm{~g} / \mathrm{L}$ xanthan and $20 \%$ glycerol $(p<0.05)$, followed by xanthan alone (which was significantly better than water and glycerol alone). Water and glycerol alone were the worst storage formulations 
for M. pulcherrima under the conditions tested here and did not differ from each other. Storage at $30^{\circ} \mathrm{C}$ caused more pronounced differences between the xanthan and glycerol formulation $(p<0.05)$ and the three other versions, which all exhibited over 100-fold less viable cells after a storage of 300 days and did not differ from each other (Figure 3B). At $22{ }^{\circ} \mathrm{C}$ and after 300 days, cells stored in glycerol or water contained $3.2 \%$ and $15.5 \%$ viable cells, respectively (as compared to the initial cell count of $1.5 \times 10^{6}$ and $1.6 \times 10^{6}$ ). Interestingly, formulations stored with xanthan exhibited an increase in cell numbers and resulted in a 5-23-fold and a 9-19-fold increase for the formulation with xanthan alone or xanthan and glycerol, respectively, resulting in a maximal CFU/mL of $8.4 \times 10^{6}$ to $1.1 \times 10^{7}$ and $1.5 \times 10^{7}$ to $2.3 \times 10^{7}$.

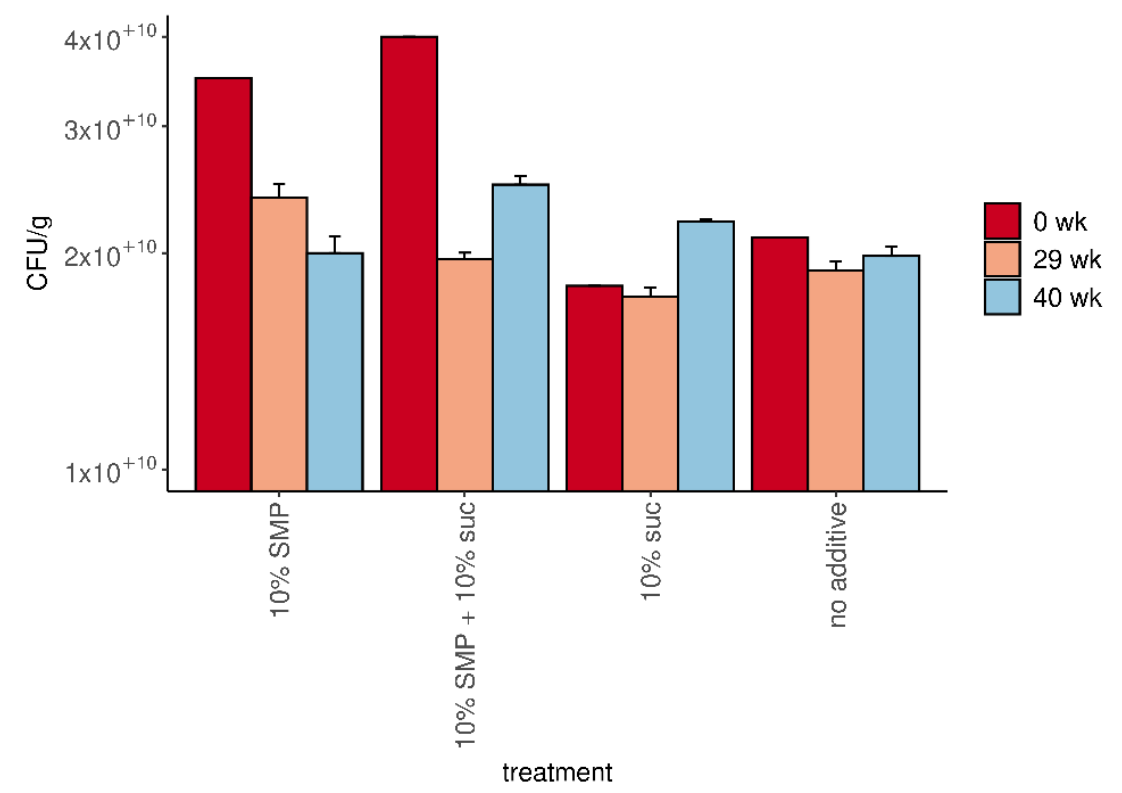

Figure 2. Skim milk powder (SMP) and sucrose do not improve long-term survival of freeze-dried M. pulcherrima cells. Freeze-dried M. pulcherrima cells were stored at $4{ }^{\circ} \mathrm{C}$ and the $\mathrm{CFU}$ was determined immediately after freeze-drying and after 7 and 9 months, respectively. Error bars represent the standard error of four replicates. No significant differences were observed.

These results suggest that $M$. pulcherrima supports liquid storage even at a temperature of $22^{\circ} \mathrm{C}$ and just in water, without any protectant.

\subsection{M. pulcherrima Is Not Able to Metabolise Xanthan}

The liquid storage experiments revealed an initial increase of the M. pulcherrima cell number in xanthan-containing formulations. We therefore tested if xanthan could serve as a carbon source and enable multiplication of $M$. pulcherrima.

Using YNB supplemented with amino acids as the basal medium, the growth of $M$. pulcherrima in the presence of glucose or xanthan as the carbon sources was quantified (a medium lacking a carbon source was used as a control). Since these culture media exhibited different turbidity, we opted for automated cell counting as a more sensitive method for determination of growth (as opposed to measuring the optical density at $600 \mathrm{~nm}$; see methods section on "Growth assays in YNB supplemented with xanthan"). While cultures grown in glucose-supplemented medium grew exponentially and reached the stationary phase after two days, cultures fed with xanthan as a carbon source did not show increased growth as compared to the negative control (Figure 4$)(p>0.05)$. This result was identically observed with xanthan from two different suppliers. However, in the xanthan containing any control media, M. pulcherrima cell number also increased, suggesting that the basal medium alone (containing amino acids) can support about two cell divisions. 


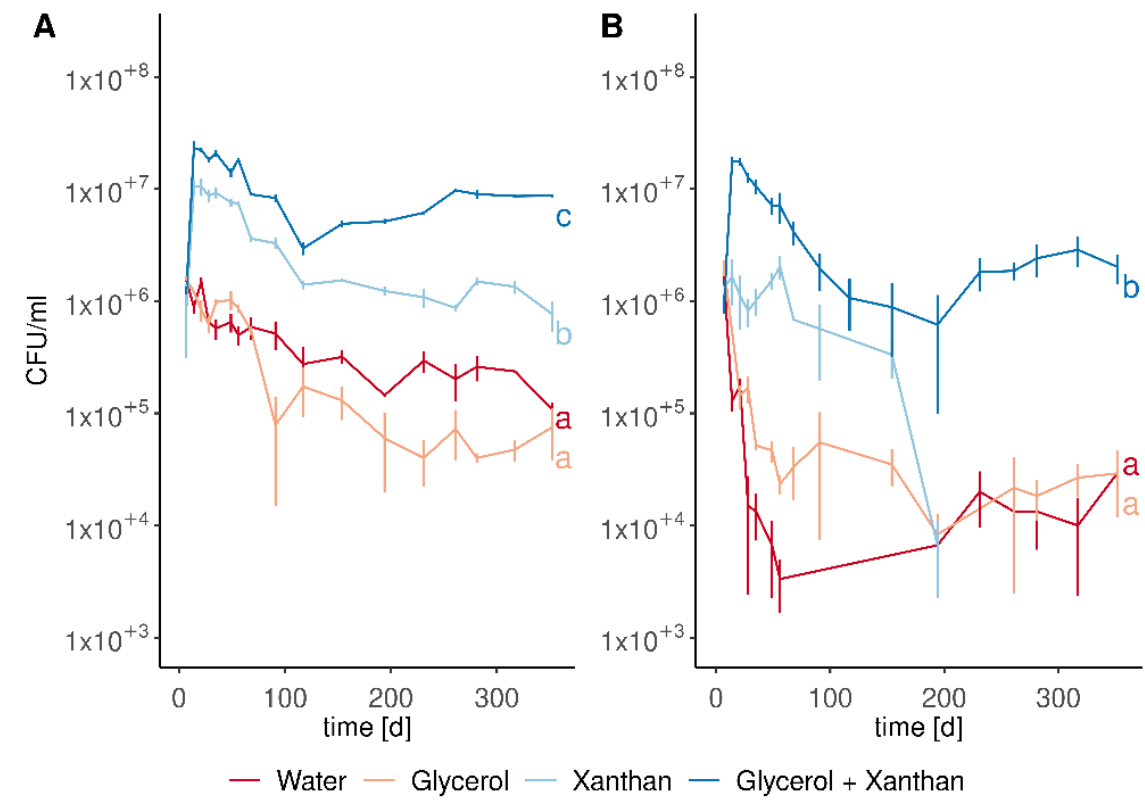

Figure 3. M. pulcherrima remains viable during long-term storage in liquid formulations and at $22{ }^{\circ} \mathrm{C}$. M. pulcherrima was stored in water, glycerol $(20 \%)$, xanthan $(5 \mathrm{~g} / \mathrm{L})$, or a combination of xanthan and glycerol and kept at $22{ }^{\circ} \mathrm{C}(\mathrm{A})$ or $30^{\circ} \mathrm{C}(\mathrm{B})$. The $\mathrm{CFU}$ was determined by serial dilutions and counting of colonies on PDA plates. After 261 days, contaminations were observed in some replicates of the samples containing glycerol or xanthan. Subsequently, these samples were omitted from determination of cell viability. Numbers are represented in a logarithmic scale. Data points represent the means and standard errors of three replicates. Letters indicate statistical significance determined by a two-sided Kruskal-Wallis test with Dunn multiple comparisons test and Benjamini-Hochberg correction $(p<0.05)$.

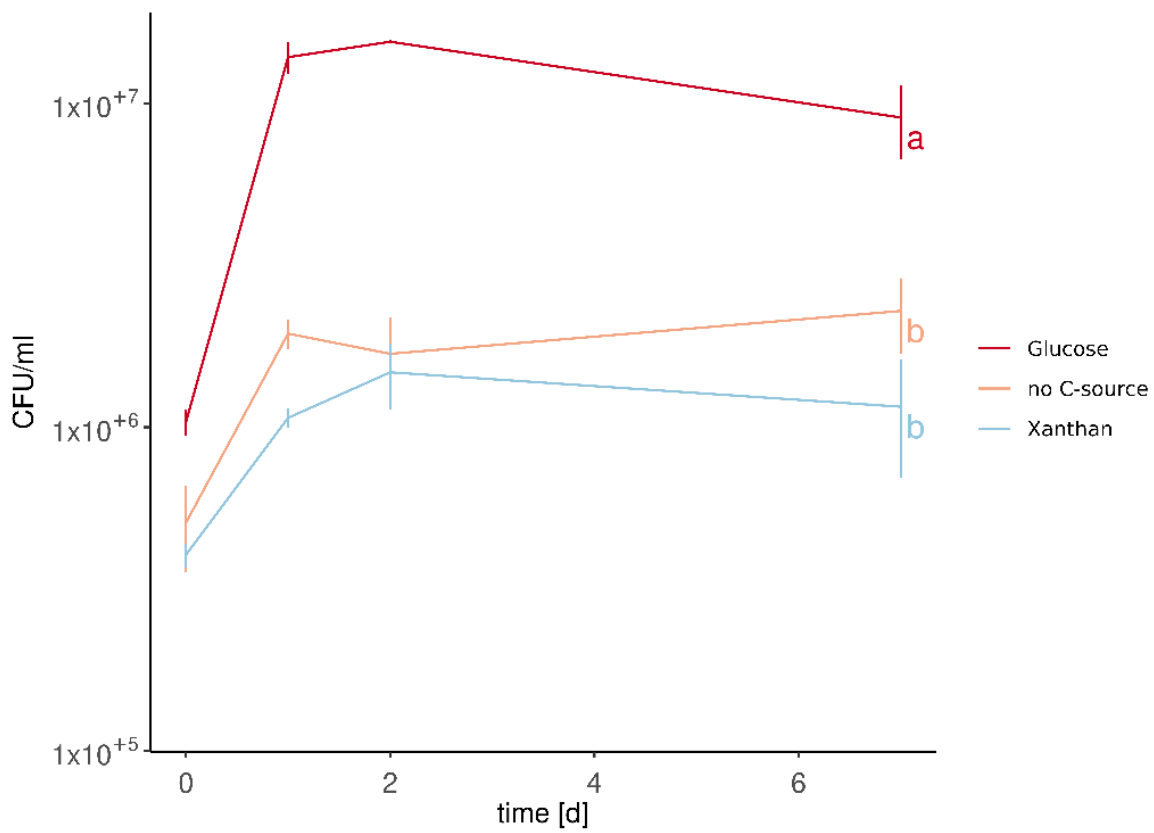

Figure 4. M. pulcherrima is not able to metabolise xanthan. M. pulcherrima was grown in YNB medium containing glucose $(5 \mathrm{~g} / \mathrm{L})$ or xanthan $(5 \mathrm{~g} / \mathrm{L})$ at $28^{\circ} \mathrm{C}$. The $\mathrm{CFU}$ was determined by counting cells using the SparkControl ${ }^{\circledR}$ cell counting app (Tecan). Numbers are represented in a logarithmic scale. The averages and standard errors of three replicates are shown. Letters indicate statistical significance determined by a two-sided Kruskal-Wallis test with Dunn multiple comparisons test and Benjamini-Hochberg correction $(p<0.05)$. 
These results suggest that xanthan metabolism is not the explanation for the increase in M. pulcherrima CFU counts upon storage.

\subsection{Formulated M. pulcherrima Cells Retain Their Antagonistic Activity against G. fujikuroi}

In order to assess if $M$. pulcherrima not only remained viable in the different dry and liquid formulations, but also retained its biocontrol activity, binary competition assays against our model fungal plant pathogen Gibberella fujikuroi were performed.

Overall, only small differences in the biocontrol activity of long-term stored M. pulcherrima cells, as compared to a freshly made overnight culture, were detected (Figure 5). For the dry formulations, no significant differences were found and an overall growth inhibition of G. fujikuroi of around 50\% was observed under the assay conditions (Figure 5A) $(p>0.05)$. For liquid M. pulcherrima formulations, cells stored in water maintained the highest biocontrol activity and showed no significant difference in comparison to the fresh overnight culture (Figure 5B) $(p>0.05)$. Cells formulated with glycerol and/or xanthan showed significantly lower biocontrol activity as compared to the overnight culture $(p<0.05)$. This effect may be partially explained by the high viscosity of the glycerol and in particular xanthan formulations, which may interfere with the exact determination of cell densities. However, the CFU of the samples used for the binary competition assays were determined by plating and colony counting and revealed comparable numbers of cells in the different samples (Figure 5C). Interestingly, cells in formulations containing glycerol showed reduced pulcherrimin production (observed as a reduction of red pigment), which could also explain the decreased biocontrol activity.
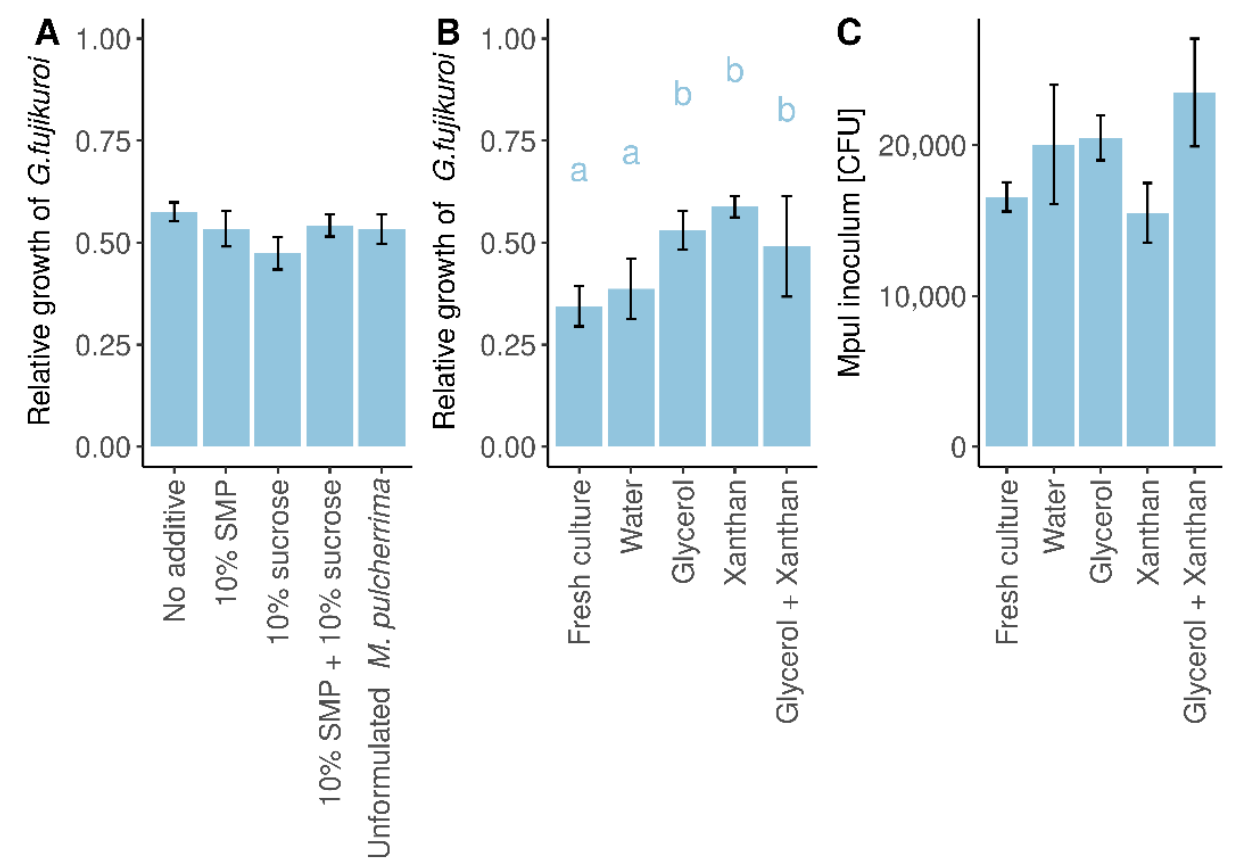

Figure 5. Formulated M. pulcherrima cells retain their antagonistic activity against G. fujikuroi. The biocontrol activity of M. pulcherrima cells stored in different dry (A) or liquid (B) formulations was tested against G. fujikuroi. As a standard, unformulated cells from an agar plate or an overnight culture of M. pulcherrima were tested. Cell densities were adjusted to obtain similar numbers of colonies on plates (C). Fungal growth was evaluated after 4 days of incubation at $22{ }^{\circ} \mathrm{C}$. The means and standard errors of four replicates are shown. Letters indicate statistical significance determined by one-way ANOVA with Tukey's multiple comparisons test and Benjamini-Hochberg correction $(p<0.05)$. There were no significant differences for the formulations in panels $(\mathbf{A}, \mathbf{C})$. 


\subsection{In Situ Competition Assays on Apple Fruit}

In order to assess if M. pulcherrima is able to suppress storage pathogens of fruit, in situ competition assays against the apple storage pathogen Neofabraea vagabunda were performed. For comparison, we included new isolates of five strongly antagonistic yeasts (A. pullulans, C. subhashii, Hanseniaspora sp., W. anomalus, and P. kluyveri [4]).

With a three-hour waiting period between the inoculation of the biocontrol yeast and the pathogen, all yeasts showed a comparable disease reduction between 50 and $70 \%$, except for $A$. pullulans, which exhibited a significantly lower efficacy under this condition (Figure 6A) $(p<0.05)$. In contrast, with a $24 \mathrm{~h}$ waiting period, A. pullulans and $W$. anomalous completely suppressed N. vagabunda, whereas M. pulcherrima and Hanseniaspora were significantly less efficacious in reducing the Neofabraea lesion diameter (Figure 6B) $(p<0.05)$.
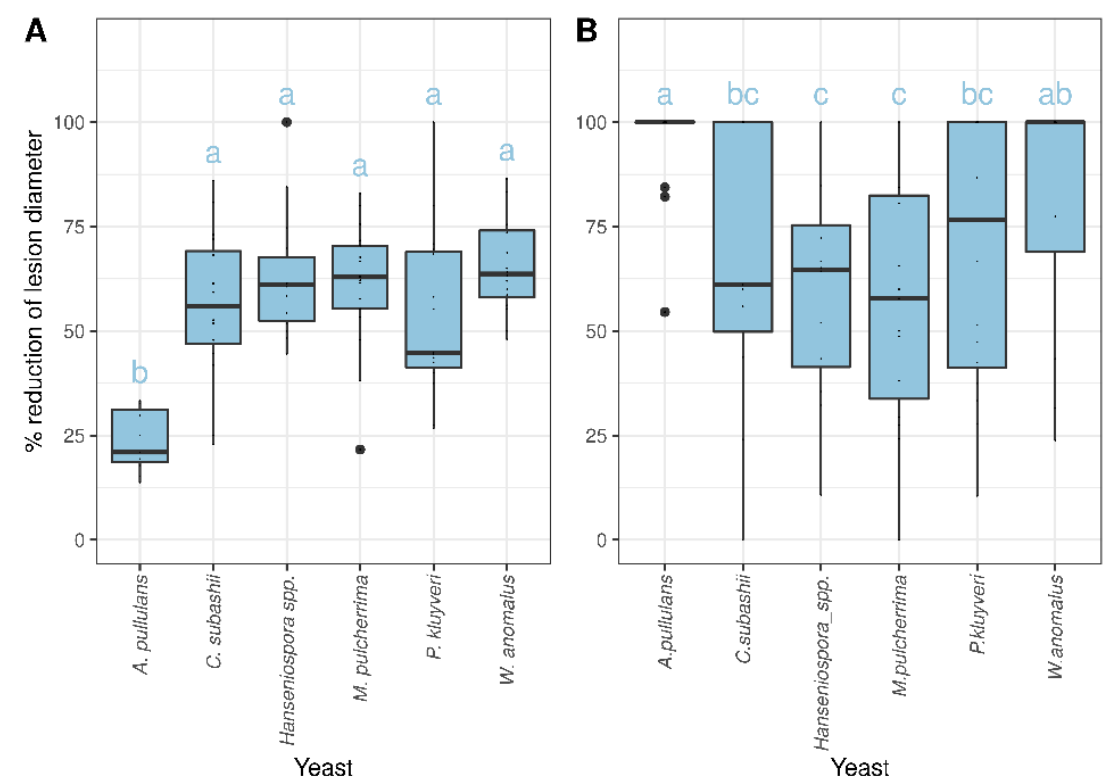

Figure 6. M. pulcherrima is able to suppress Neofabraea rot of apples. In situ competition assays against the apple storage pathogen Neofabraea vagabunda were performed with six strains of strongly antagonistic yeasts (Aureobasidium pullulans, Candida subhashii, Hanseniaspora sp., M. pulcherrima, Wickerhamomyces anomalus, and Pichia kluyveri). The pathogen was added $3 \mathrm{~h}$ (A) or $24 \mathrm{~h}$ (B) after the yeasts were added to artificial lesions. For each yeast, the reduction of the Neofabraea lesion diameter was determined in 10 apples. The whole experiment was performed twice. Letters indicate statistical significance determined by one-way ANOVA with Tukey's multiple comparisons test and Benjamini-Hochberg correction $(p<0.05)$.

These results demonstrate that $M$. pulcherrima is able to suppress one of the most important apple storage diseases in Europe caused by N. vagabunda. The different results obtained with the two waiting periods suggests that various yeasts may be most effective at different time points.

\subsection{Field Trial Data}

In order to further test M. pulcherrima and gain experience with field applications of this yeast, trials against apple postharvest diseases have been carried out since 2016. Since bull's eye rot caused by Neofabreae spp. was the main disease on the stored apples in previous trials, the infection with this pathogen is shown for all five field trials from the years 2016-2020. The disease pressure in the untreated control varied depending on the year (between approximately 5\% in 2020 and almost 35\% in 2017) (Figure 7). In each trial, the treatment with captan and trifloxystrobin (CF) reduced the infection by Neofabreae. In 2016, an additive effect was shown by two M. pulcherrima treatments after prior application of 
captan and trifloxystrobin (CF + 2xMpul; Figure 7A). Neither the three treatments with the reference biocontrol product BlossomProtect ${ }^{\mathrm{TM}}$ (BP; A. pullulans) nor the three treatments with M. pulcherrima (both without prior use of captan and trifloxystrobin) reduced the infection. In 2017, the additive effect of two M. pulcherrima treatments following the prior application of captan and trifloxystrobin could be confirmed (Figure 7B). In 2018, two different M. pulcherrima formulations were tested. Neither formulation reduced Neofabreae incidence as compared to the treatment with captan and trifloxystrobin alone (Figure 7C). In 2019, M. pulcherrima was combined with a reduced amount of trifloxystrobin and captan was omitted and two applications with M. pulcherrima alone followed thereafter. Nevertheless, the percentage of infected apples (by weight, of the total harvest) was also reduced to $10 \%$, as with the standard captan and trifloxystrobin application (Figure 7D). Five $M$. pulcherrima treatments (without the initial inclusion of fungicides) did not reduce Neofabreae infection. Postharvest application of $M$. pulcherrima also did not reduce the infection by Neofabrea. In 2020, only $5 \%$ of the untreated control apples (by weight, of the total harves) was infected with Neofabrea (Figure 7E). The application of two different M. pulcherrima concentrations did not show any beneficial effect.
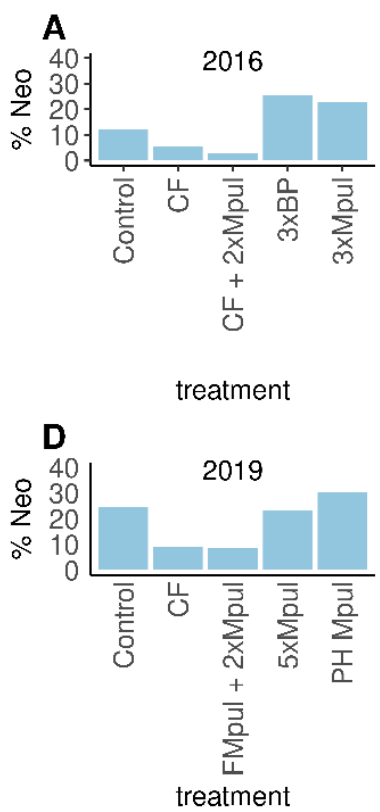

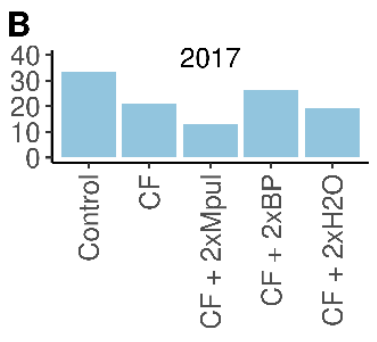

treatment

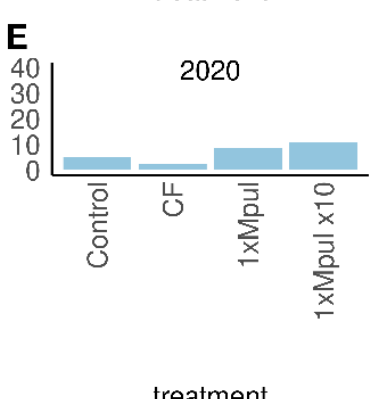

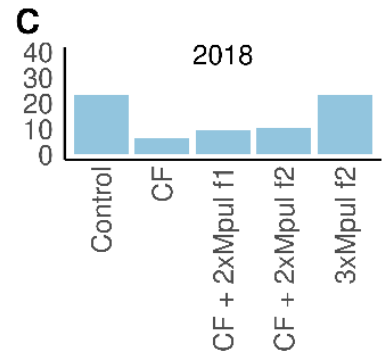

treatment

Figure 7. Field application of M. pulcherrima following fungicide treatments reduces Neofabraea rot in stored apples in some years. Field trials with M. pulcherrima have been carried out since 2016 in an experimental orchard in Switzerland. The percentage of apples (based on weight of the total harvest of all four replicates) with signs of Neofabraea rot is shown for each year from 2016 to 2020 (panels A-E). Treatments were compared to an untreated control and an integrated pest management control comprised of one Captan (captan) $0.125 \%$ and Flint (trifloxystrobin) $0.015 \%$ (CF) application 21 days before harvest. Yeast and control treatments $\left(\mathrm{H}_{2} \mathrm{O}\right)$ were either applied twice (10-14 and 3 days prior to harvest) after a prior CF treatment or three times if no CF treatment was used (21, 10-14, and 3 days before harvest). The treatments included M. pulcherrima (Mpul) or, for comparison, the commercially available product BlossomProtect ${ }^{\mathrm{TM}}$ (BP). In 2018, the Mpul treatment was applied as formulation 1 (f1) or as formulation 2 (f2). In 2019, the first Mpul treatment was applied premixed with a reduced amount of fungicide (FMpul) and as a postharvest treatment (PH Mpul). In 2020, one treatment consisted of a $10 \times$ Mpul concentration.

\section{Discussion}

M. pulcherrima is a well-known biocontrol organism against different fungal pathogens, mainly on fruits [2-4,6-8], but currently no plant protection product containing this species as an active ingredient is marketed. For the development of a biocontrol agent, many aspects, from strain selection, production, formulation, and storability, to application 
technology, biosafety, and registration, have to be covered and addressed in order to develop an efficacious and economically viable product. Here, we assessed the behavior of M. pulcherrima during long-term storage in dry and liquid formulations and employed a test product in a first series of field trials against apple postharvest diseases.

M. pulcherrima cells exhibited an exceptionally long shelf life and survived for many months and years in liquid and dry form, even without protective additives such as SMP, sucrose, glycerol, or xanthan. This finding underlines their remarkable stress resistance and stability, which have been described previously and are often named as advantageous properties for potential biocontrol products [1,33]. Freeze-drying in particular is a preservation method that results in cells able to withstand storage over many years; up to 20 years with minimal yearly reduction of cell viability have been reported [34,35]. Liquid formulations have also been tested, but only for shorter storage periods and overall fewer studies are published. For the biocontrol yeast Pichia anomala, the addition of trehalose improved survival and resulted in $22 \%$ of cells surviving storage for 12 weeks at $20^{\circ} \mathrm{C}$ [36]. For Pichia guilliermondi and Rhodotorula mucilaginosa, liquid formulations with wheat- or rice-bran were most effective and improved survival over a storage period of six months [37]. For Rhodotorula minuta, a combination of glycerol and xanthan in a phosphate buffer was suitable for up to six months of storage at $4{ }^{\circ} \mathrm{C}$, albeit with a reduction in viable cells of two orders of magnitude [38].

The four commercial, dry formulations tested here all contained similar amounts of living cells per dry weight, but the addition of SMP and/or sucrose significantly increased the amount of final product due to the added dry weight of the additives. Consequently, the additives must have improved survival during the freeze-drying procedure. With the addition of sucrose and SMP, the survival of freeze-drying was $72 \%$, while it only measured $12-43 \%$ for the other three treatments. During consecutive storage, only minimal losses of viability were observed for all four formulations. These survival percentages for the freeze-drying process are comparable to the maximum survival of $64.2 \%$ obtained for $M$. pulcherrima by the addition of $25 \%(w / v)$ maltose and the optimization of culture conditions and cell density [39]. In general, this is in agreement with earlier studies that identified freeze-drying, and not the long-term storage, as the most critical step and the cause for much higher cell death $[34,40]$.

At the moment, it is not clear why the combination of SMP and sucrose had a synergistic effect on survival of freeze-drying. Tests with different concentrations of additives and using different cell densities for freeze-drying are necessary to better understand this result. However, over $70 \%$ of survival during freeze-drying and the minimal loss of viability even after several years of storage are promising results and compare well with other yeasts $[34,39,41]$. To further improve survival of freeze-drying, other additives, in particular sugars that often function as lyoprotectants for different microorganisms, could be tested [42-45]. The protective action of SMP has been documented for different microorganisms and in some cases beneficial effects of combinations with sugars have also been detected $[25,41,46]$. In a study on yeasts naturally present on Kefir grains, the survival during freeze-drying could be increased up to $80 \%$ by increasing the concentration of lyoprotectants (galactose and sucrose) from 1 to $10 \%$ [44]. In contrast, P. anomala viability during long-term storage was dramatically decreased when higher amounts (20 and 35\%) of the lyoprotectant were used [42]. Apart from lyoprotectants, the growth conditions in the bioreactor and procedures before freeze-drying are important as well. For generating the test products used here, the culture $\mathrm{pH}$ was lowered to 5.5 , the growth reduced to $24.2 \mathrm{~h}$ (instead of $29 \mathrm{~h}$ at $\mathrm{pH} 6.5$ ), and freezing at $-20^{\circ} \mathrm{C}$ before freeze-drying was prolonged for consecutive production batches. These adaptations may all have contributed to the exceptional survival and storage properties obtained for the M. pulcherrima product developed here.

In contrast to dry formulations, liquid preparations are much less studied despite their promise due to the easy handling during production and application. In the initial experiments presented here, we showed that liquid M. pulcherrima formulations maintain viability 
and biocontrol activity over several months, even when only kept in water and at 22 or $30{ }^{\circ} \mathrm{C}$. It should thus be possible to further improve this survival; for example, by reducing the storage temperature, altering and better controlling culture conditions prior to storage, or including other additives that help maintain viability and prevent sedimentation.

Survival and cell viability in water have been studied extensively in the context of aging, life span extension, and calorie restriction in Saccharomyces cerevisiae: Transferring S. cerevisiae cells to water stops growth, slows aging, and dramatically increases life span [47-54]. This phenomenon likely explains the long-term survival of M. pulcherrima in the liquid formulations tested here. However, the addition of carbon sources (in the absence of all other nutrients required for growth), even just as a short pulse, leads to a decline of cell viability within two to three weeks [48,54]. In contrast, in the case described here, the presence of glycerol did not trigger a rapid loss of cell viability and had a similar effect as water alone. However, cells formulated only in water did perform the best in biocontrol assays, while those kept in glycerol showed impaired biocontrol activity, suggesting that a water-based $M$. pulcherrima formulation may indeed be a promising application for plant protection. In addition, the cells formulated in water were never contaminated, even after more than 300 days, while some samples containing glycerol or xanthan did show contaminations after 261 days. Apart from reduced biocontrol activity, glycerol storage caused a noticeable number of cells to lose pulcherrimin production. Loss of pulcherrimin biosynthesis during long-term storage has been observed previously and may be responsible for a reduction in biocontrol activity [2,9].

Interestingly, in our case, the presence of xanthan resulted in an initial increase of the cell number and it seemed as if M. pulcherrima cells continued to divide for a period of two to three weeks (3-4 cell divisions in total) before cell counts started to decline again. This effect was observed in all repetitions of this experiment, at different temperatures (22 and $30{ }^{\circ} \mathrm{C}$ ) and with xanthan from different suppliers. According to our experiments, xanthan could not be used as a carbon source by M. pulcherrima, and it only contained minimal amounts of glucose (not shown). Microscopic observation and cell size measurements did not reveal apparent differences in cell size or shape for the different liquid formulations. At the moment, the underlying cause for this observation is thus not known. Xanthan is a complex polysaccharide with interesting properties for industrial applications, particularly in the food industry, and is, for example, used to increase viscosity, reduce shearing forces, prevent sedimentation, or homogenize solutions [55-57]. Interestingly, in mixtures with other polymers (e.g., gelatin, different mannans, guar gum), xanthan can form gels and exhibits novel properties [58-63]. It may thus be possible that xanthan also interacts with some of the polymers in the M. pulcherrima cell wall and thereby generates a gel-like structure at the cell surface, which may protect and stabilize the yeast cells. Future studies on the effect of xanthan on M. pulcherrima cells will have to study this effect in detail. The, so far, inexplicable increase in cell counts and exceptional stability of M. pulcherrima in xanthan certainly justify pursuing xanthan-based formulations further. These studies will on one hand address basic functions and effects of xanthan on the yeast cell, but also develop a xanthan-based yeast formulation for the long-term preservation of viable, active biocontrol yeast cells.

The field trials with M. pulcherrima documented a reduction in Neofabreae rot of stored apples (as compared to the control treatment), in particular in the years 2016, 2017, and 2019 and when the yeast was used after prior fungicide applications. This effect was repeatedly observed. However, the efficacy of $M$. pulcherrima varied from year to year; as did Neofabraea incidence in the untreated control apples. In years with low disease pressure, such as 2020, even the fungicide applications had little effect and the yeast treatment seemed to increase Neofabraea rot. Based on these results, two M. pulcherrima applications after a conventional treatment scheme, ending with captan and trifloxystrobin 21 days before harvest, seem a promising potential application. Presumably, the prior fungicide treatments clean the apple surface and thus enable $M$. pulcherrima to create a protective layer around the fruits preventing infection of Neofabraea spores before harvest. 
Overall, this work reports highly advantageous storage properties of M. pulcherrima and encouraging results for the possible development of a novel postharvest plant protection application. Although these are important first steps towards an application, there is ample room for making the production, storage, and application of $M$. pulcherrima more reliable. Better understanding the factors responsible for survival of $M$. pulcherrima during production, in the field, and during storage is required in order to develop a reliable and efficacious plant protection product that is based on this yeast as the active ingredient.

Author Contributions: A.B., conceptualization, methodology, formal analysis, investigation, writing, project administration; S.K., methodology, formal analysis, investigation; L.M., methodology, formal analysis, investigation; M.H.-B., investigation, resources; S.P., conceptualization, methodology, formal analysis, writing, project administration; F.M.F., conceptualization, formal analysis, writing, project administration. All authors have read and agreed to the published version of the manuscript.

Funding: FMF received funding from the Swiss National Science Foundation (SNSF, grant 31003A_175665).

Acknowledgments: Andreas Naef and the field trial team of Matthias Schmid are greatly acknowledged for performing and supporting the field applications and experiments. We thank Sonia Petignat and Daniel Feusi for providing the apple storage facilities and numerous colleagues at Agroscope for evaluating the diseases of the stored apples. Liesa Kunz and Lena Dändliker helped with competition assays in the laboratory.

Conflicts of Interest: The authors declare no conflict of interest.

\section{References}

1. Freimoser, F.M.; Rueda-Mejia, M.P.; Tilocca, B.; Migheli, Q. Biocontrol Yeasts: Mechanisms and Applications. World J. Microbiol. Biotechnol. 2019, 35, 154. [CrossRef] [PubMed]

2. Gore-Lloyd, D.; Sumann, I.; Brachmann, A.O.; Schneeberger, K.; Ortiz-Merino, R.A.; Moreno-Beltrán, M.; Schläfli, M.; Kirner, P.; Santos Kron, A.; Rueda-Mejia, M.P.; et al. Snf2 Controls Pulcherriminic Acid Biosynthesis and Antifungal Activity of the Biocontrol Yeast Metschnikowia pulcherrima. Mol. Microbiol. 2019, 112, 317-332. [CrossRef]

3. Vadkertiova, R.; Molnarova, J.; Vranova, D.; Slavikova, E. Yeasts and Yeast-like Organisms Associated with Fruits and Blossoms of Different Fruit Trees. Can. J. Microbiol. 2012, 58, 1344-1352. [CrossRef] [PubMed]

4. Hilber-Bodmer, M.; Schmid, M.; Ahrens, C.H.; Freimoser, F.M. Competition Assays and Physiological Experiments of Soil and Phyllosphere Yeasts Identify Candida subhashii as a Novel Antagonist of Filamentous Fungi. BMC Microbiol. 2017, 17, 4. [CrossRef] [PubMed]

5. Droby, S.; El-Gerberia, B. Yeast Metschnikowia Fructicola NRRL Y-30752 for Inhibiting Deleterious Microorganisms on Plants. U.S. Patent No. 6,994,849, 2 February 2006.

6. Pawlikowska, E.; James, S.A.; Breierova, E.; Antolak, H.; Kregiel, D. Biocontrol Capability of Local Metschnikowia sp. Isolates. Antonie Van Leeuwenhoek 2019, 112, 1425-1445. [CrossRef]

7. Turkel, S.; Korukluoglu, M.; Yavuz, M. Biocontrol Activity of the Local Strain of Metschnikowia pulcherrima on Different Postharvest Pathogens. Biotechnol. Res. Int. 2014, 2014, 397167. [CrossRef]

8. Turkel, S.; Ener, B. Isolation and Characterization of New Metschnikowia pulcherrima Strains as Producers of the Antimicrobial Pigment Pulcherrimin. Z. Naturforsch. C 2009, 64, 405-410. [CrossRef]

9. Sipiczki, M. Metschnikowia Strains Isolated from Botrytized Grapes Antagonize Fungal and Bacterial Growth by Iron Depletion. Appl. Environ. Microbiol. 2006, 72, 6716-6724. [CrossRef] [PubMed]

10. Contreras, A.; Curtin, C.; Varela, C. Yeast Population Dynamics Reveal a Potential "collaboration" between Metschnikowia pulcherrima and Saccharomyces uvarum for the Production of Reduced Alcohol Wines during Shiraz Fermentation. Appl. Microbiol. Biotechnol. 2015, 99, 1885-1895. [CrossRef] [PubMed]

11. Contreras, A.; Hidalgo, C.; Henschke, P.A.; Chambers, P.J.; Curtin, C.; Varela, C. Evaluation of Non-Saccharomyces Yeasts for the Reduction of Alcohol Content in Wine. Appl. Environ. Microbiol. 2014, 80, 1670-1678. [CrossRef]

12. Chantasuban, T.; Santomauro, F.; Gore-Lloyd, D.; Parsons, S.; Henk, D.; Scott Roderick, J.; Chuck, C. Elevated Production of the Aromatic Fragrance Molecule, 2-phenylethanol, Using Metschnikowia pulcherrima through Both de Novo and Ex Novo Conversion in Batch and Continuous Modes. J. Chem. Technol. Biotechnol. 2018, 93, 2118-2130. [CrossRef] [PubMed]

13. Santamauro, F.; Whiffin, F.M.; Scott, R.J.; Chuck, C.J. Low-Cost Lipid Production by an Oleaginous Yeast Cultured in Non-Sterile Conditions Using Model Waste Resources. Biotechnol. Biofuels 2014, 7, 34. [CrossRef] [PubMed]

14. de la Cruz Quiroz, R.; Cruz Maldonado, J.J.; Rostro Alanis, M.D.J.; Torres, J.A.; Parra Saldívar, R. Fungi-Based Biopesticides: Shelf-Life Preservation Technologies Used in Commercial Products. J. Pest Sci. 2019, 92, 1003-1015. [CrossRef]

15. Chaudhary, T.; Dixit, M.; Gera, R.; Shukla, A.K.; Prakash, A.; Gupta, G.; Shukla, P. Techniques for Improving Formulations of Bioinoculants. 3 Biotech 2020, 10, 199. [CrossRef] [PubMed] 
16. Marian, M.; Shimizu, M. Improving Performance of Microbial Biocontrol Agents against Plant Diseases. J. Gen. Plant Pathol. 2019, 85, 329-336. [CrossRef]

17. Rao, M.S.; Umamaheswari, R.; Chakravarthy, A.K.; Grace, G.N.; Kamalnath, M.; Prabu, P. A Frontier Area of Research on Liquid Biopesticides: The Way Forward for Sustainable Agriculture in India. Curr. Sci. 2015, 108, 3.

18. Gasic, S.; Tanovic, B. Biopesticide Formulations, Possibility of Application and Future Trends. Pestic. Fitomedicina 2013, 28 , 97-102. [CrossRef]

19. Bashan, Y.; de-Bashan, L.E.; Prabhu, S.R.; Hernandez, J.-P. Advances in Plant Growth-Promoting Bacterial Inoculant Technology: Formulations and Practical Perspectives (1998-2013). Plant Soil 2014, 378, 1-33. [CrossRef]

20. Bashir, O.; Claverie, J.P.; Lemoyne, P.; Vincent, C. Controlled-Release of Bacillus thurigiensis Formulations Encapsulated in Light-Resistant Colloidosomal Microcapsules for the Management of Lepidopteran Pests of Brassica Crops. PeerJ 2016, 4, e2524. [CrossRef] [PubMed]

21. Shao, H.; Xi, N.; Zhang, Y. Microemulsion Formulation of a New Biopesticide to Control the Diamondback Moth (Lepidoptera: Plutellidae). Sci. Rep. 2018, 8, 10565. [CrossRef]

22. Yaakov, N.; Ananth Mani, K.; Felfbaum, R.; Lahat, M.; Da Costa, N.; Belausov, E.; Ment, D.; Mechrez, G. Single Cell Encapsulation via Pickering Emulsion for Biopesticide Applications. ACS Omega 2018, 3, 14294-14301. [CrossRef]

23. Yang, Y.; Fang, Z.; Chen, X.; Zhang, W.; Xie, Y.; Chen, Y.; Liu, Z.; Yuan, W. An Overview of Pickering Emulsions: Solid-Particle Materials, Classification, Morphology, and Applications. Front. Pharmacol. 2017, 8, 287. [CrossRef] [PubMed]

24. Berninger, T.; López, Ó.G.; Bejarano, A.; Preininger, C.; Sessitsch, A. Maintenance and Assessment of Cell Viability in Formulation of Non-Sporulating Bacterial Inoculants. Microb. Biotechnol. 2018, 11, 277-301. [CrossRef]

25. Abadias, M.; Teixido, N.; Usall, J.; Benabarre, A.; Vinas, I. Viability, Efficacy, and Storage Stability of Freeze-Dried Biocontrol Agent Candida sake Using Different Protective and Rehydration Media. J. Food Prot. 2001, 64, 856-861. [CrossRef] [PubMed]

26. Aguirre-Güitrón, L.; Calderón-Santoyo, M.; Ortiz-Basurto, R.I.; Bautista-Rosales, P.U.; Ragazzo-Sánchez, J.A. Optimisation of the Spray Drying Process of Formulating the Post-Harvest Biocontrol Agent Meyerozyma caribbica. Biocontrol Sci. Technol. 2018, 28, 574-590. [CrossRef]

27. Kunz, S. Development of "Blossom-Protect"-A Yeast Preparation for the Reduction of Blossom Infections by Fire Blight. In Proceedings of the 11th International Conference on Cultivation Technique and Phytopathological Problems in Organic Fruit-Growing, Weinsberg, Germany, 3-5 February 2004; Boos, M., Ed.; Fördergemeinschaft Ökologischer Obstbau-FÖKO: Weinsberg, Germany, 2004.

28. Droby, S.; Cohen, L.; Daus, A.; Weiss, B.; Horev, B.; Chalutz, E.; Katz, H.; Keren-Tzur, M.; Shachnai, A. Commercial Testing of Aspire: A Yeast Preparation for the Biological Control of Postharvest Decay of Citrus. Biol. Control 1998, 12, 97-101. [CrossRef]

29. Nilsson, R.H.; Larsson, K.H.; Taylor, A.F.S.; Bengtsson-Palme, J.; Jeppesen, T.S.; Schigel, D.; Kennedy, P.; Picard, K.; Glockner, F.O.; Tedersoo, L.; et al. The UNITE Database for Molecular Identification of Fungi: Handling Dark Taxa and Parallel Taxonomic Classifications. Nucleic Acids Res. 2018, 47, D259-D264. [CrossRef] [PubMed]

30. Rueda-Mejia, M.P.; Nägeli, L.; Lutz, S.; Hayes, R.D.; Varadarajan, A.R.; Grigoriev, I.V.; Ahrens, C.H.; Freimoser, F.M. Genome, Transcriptome and Secretome Analyses of the Antagonistic, Yeast-like Fungus Aureobasidium pullulans to Identify Potential Biocontrol Genes. Microb Cell 2021, 8, 184-202. [CrossRef] [PubMed]

31. Magoye, E.; Hilber-Bodmer, M.; Pfister, M.; Freimoser, F.M. Unconventional Yeasts Are Tolerant to Common Antifungals, and Aureobasidium pullulans Has Low Baseline Sensitivity to Captan, Cyprodinil, and Difenoconazole. Antibiotics 2020, 9, 602. [CrossRef]

32. Köhl, J.; Wenneker, M.; Haas, B.H.G.; Anbergen, R.; de Geijn, H.M.G.; der Plas, C.H.L.; Pinto, F.A.M.F.; Kastelein, P. Dynamics of Post-Harvest Pathogens Neofabraea spp. and Cadophora spp. in Plant Residues in Dutch Apple and Pear Orchards. Plant Pathol. 2018, 67, 1264-1277. [CrossRef]

33. Mukherjee, V.; Radecka, D.; Aerts, G.; Verstrepen, K.J.; Lievens, B.; Thevelein, J.M. Phenotypic Landscape of Non-Conventional Yeast Species for Different Stress Tolerance Traits Desirable in Bioethanol Fermentation. Biotechnol. Biofuels 2017, 10, 216. [CrossRef]

34. Miyamoto-Shinohara, Y.; Sukenobe, J.; Imaizumi, T.; Nakahara, T. Survival Curves for Microbial Species Stored by Freeze-Drying. Cryobiology 2006, 52, 27-32. [CrossRef] [PubMed]

35. Bond, C. Freeze-Drying of Yeast Cultures. Methods Mol. Biol. 2007, 368, 99-107. [CrossRef] [PubMed]

36. Melin, P.; Hakansson, S.; Eberhard, T.H.; Schnurer, J. Survival of the Biocontrol Yeast Pichia anomala after Long-Term Storage in Liquid Formulations at Different Temperatures, Assessed by Flow Cytometry. J. Appl. Microbiol. 2006, 100, 264-271. [CrossRef] [PubMed]

37. Mokhtarnejad, L.; Etebarian, H.R.; Fazeli, M.R.; Jamalifar, H. Evaluation of Different Formulations of Potential Biocontrol Yeast Isolates Efficacy on Apple Blue Mold at Storage Condition. Arch. Phytopathol. Plant Prot. 2011, 40, 970-980. [CrossRef]

38. Patino-Vera, M.; Jimenez, B.; Balderas, K.; Ortiz, M.; Allende, R.; Carrillo, A.; Galindo, E. Pilot-Scale Production and Liquid Formulation of Rhodotorula minuta, a Potential Biocontrol Agent of Mango Anthracnose. J. Appl. Microbiol. 2005, 99, 540-550. [CrossRef]

39. Spadaro, D.; Ciavorella, A.A.; Lopez-Reyes, J.G.; Garibaldi, A.; Gullino, M.L. Effect of Culture Age, Protectants, and Initial Cell Concentration on Viability of Freeze-Dried Cells of Metschnikowia pulcherrima. Can. J. Microbiol. 2010, 56, 809-815. [CrossRef] [PubMed] 
40. Miyamoto-Shinohara, Y.; Imaizumi, T.; Sukenobe, J.; Murakami, Y.; Kawamura, S.; Komatsu, Y. Survival Rate of Microbes after Freeze-Drying and Long-Term Storage. Cryobiology 2000, 41, 251-255. [CrossRef]

41. Polomska, X.; Wojtatowicz, M.; Zarowska, B.; Szołtysik, M.; Chrzanowska, J. Freeze-Drying Preservation of Yeast Adjunct Cultures for Cheese Production. Pol. J. Food Nutr. Sci. 2012, 62, 143-150. [CrossRef]

42. Melin, P.; Hakansson, S.; Schnurer, J. Optimisation and Comparison of Liquid and Dry Formulations of the Biocontrol Yeast Pichia Anomala J121. Appl. Microbiol. Biotechnol. 2007, 73, 1008-1016. [CrossRef]

43. Costa, E.; Usall, J.; Teixidó, N.; Garcia, N.; Viñas, I. Effect of Protective Agents, Rehydration Media and Initial Cell Concentration on Viability of Pantoea Agglomerans Strain CPA-2 Subjected to Freeze-Drying. J. Appl. Microbiol. 2000, 89, 793-800. [CrossRef]

44. Chen, H.-C.; Lin, C.-W.; Chen, M.-J. The Effects of Freeze Drying and Rehydration on Survival of Microorganisms in Kefir. Asian-Australas. J. Anim. Sci. 2006, 19, 126-130. [CrossRef]

45. Li, B.Q.; Tian, S.P. Effects of Trehalose on Stress Tolerance and Biocontrol Efficacy of Cryptococcus laurentii. J. Appl. Microbiol. 2006, 100, 854-861. [CrossRef] [PubMed]

46. Huang, L.; Lu, Z.; Yuan, Y.; Lü, F.; Bie, X. Optimization of a Protective Medium for Enhancing the Viability of Freeze-Dried Lactobacillus delbrueckii Subsp. Bulgaricus Based on Response Surface Methodology. J. Ind. Microbiol. Biotechnol. 2006, 33 , 55-61. [CrossRef] [PubMed]

47. Cohen, A.; Weindling, E.; Rabinovich, E.; Nachman, I.; Fuchs, S.; Chuartzman, S.; Gal, L.; Schuldiner, M.; Bar-Nun, S. WaterTransfer Slows Aging in Saccharomyces Cerevisiae. PLoS ONE 2016, 11, e0148650. [CrossRef]

48. Granot, D.; Snyder, M. Carbon Source Induces Growth of Stationary Phase Yeast Cells, Independent of Carbon Source Metabolism. Yeast 1993, 9, 465-479. [CrossRef]

49. Longo, V.D.; Mattson, M.P. Fasting: Molecular Mechanisms and Clinical Applications. Cell Metab. 2014, 19, 181-192. [CrossRef]

50. Wei, M.; Fabrizio, P.; Hu, J.; Ge, H.; Cheng, C.; Li, L.; Longo, V.D. Life Span Extension by Calorie Restriction Depends on Rim15 and Transcription Factors Downstream of Ras/PKA, Tor, and Sch9. PLoS Genet. 2008, 4, e13. [CrossRef] [PubMed]

51. Fabrizio, P.; Hoon, S.; Shamalnasab, M.; Galbani, A.; Wei, M.; Giaever, G.; Nislow, C.; Longo, V.D. Genome-Wide Screen in Saccharomyces cerevisiae Identifies Vacuolar Protein Sorting, Autophagy, Biosynthetic, and TRNA Methylation Genes Involved in Life Span Regulation. PLoS Genet. 2010, 6, e1001024. [CrossRef] [PubMed]

52. Aris, J.P.; Alvers, A.L.; Ferraiuolo, R.A.; Fishwick, L.K.; Hanvivatpong, A.; Hu, D.; Kirlew, C.; Leonard, M.T.; Losin, K.J.; Marraffini, M.; et al. Autophagy and Leucine Promote Chronological Longevity and Respiration Proficiency during Calorie Restriction in Yeast. Exp. Gerontol. 2013, 48, 1107-1119. [CrossRef]

53. Burtner, C.R.; Murakami, C.J.; Kennedy, B.K.; Kaeberlein, M. A Molecular Mechanism of Chronological Aging in Yeast. Cell Cycle 2009, 8, 1256-1270. [CrossRef] [PubMed]

54. Granot, D.; Snyder, M. Glucose Induces CAMP-Independent Growth-Related Changes in Stationary-Phase Cells of Saccharomyces cerevisiae. Proc. Natl. Acad. Sci. USA 1991, 88, 5724-5728. [CrossRef] [PubMed]

55. Winkler, S.; Kaplan, D.L. Biosynthesized Materials: Properties and Processing. In Encyclopedia of Materials: Science and Technology; Buschow, K.H.J., Cahn, R.W., Flemings, M.C., Ilschner, B., Kramer, E.J., Mahajan, S., Veyssière, P., Eds.; Elsevier: Oxford, UK, 2001; pp. 609-615. ISBN 978-0-08-043152-9.

56. Williams, P.A.; Phillips, G.O. GUMS-Properties of Individual Gums. In Encyclopedia of Food Sciences and Nutrition, 2nd ed.; Caballero, B., Ed.; Academic Press: Oxford, UK, 2003; pp. 2992-3001. ISBN 978-0-12-227055-0.

57. Kulkarni, V.S.; Shaw, C. Chapter 5-Use of Polymers and Thickeners in Semisolid and Liquid Formulations. In Essential Chemistry for Formulators of Semisolid and Liquid Dosages; Kulkarni, V.S., Shaw, C., Eds.; Academic Press: Boston, MA, USA, 2016; pp. 43-69. ISBN 978-0-12-801024-2.

58. Morris, E.R. Mixed Polymer Gels. In Food Gels; Harris, P., Ed.; Elsevier Applied Food Science Series; Springer: Dordrecht, The Netherlands, 1990; pp. 291-359. ISBN 978-94-009-0755-3.

59. Iijima, M.; Shinozaki, M.; Hatakeyama, T.; Takahashi, M.; Hatakeyama, H. AFM Studies on Gelation Mechanism of Xanthan Gum Hydrogels. Carbohydr. Polym. 2007, 68, 701-707. [CrossRef]

60. Wang, C.-S.; Virgilio, N.; Wood-Adams, P.; Heuzey, M.-C. A Mechanism for the Synergistic Gelation Properties of Gelatin B and Xanthan Gum Aqueous Mixtures. Carbohydr. Polym. 2017, 175, 484-492. [CrossRef] [PubMed]

61. Williams, P.A.; Clegg, S.M.; Day, D.H.; Phillips, G.O.; Nishinari, K. Mixed Gels Formed with Konjac Mannan and Xanthan Gum. In Food Polymers, Gels and Colloids; Dickinson, E., Ed.; Woodhead Publishing: Sawston, UK, 1991; pp. 339-348. ISBN 978-1-85573-787-7.

62. Williams, P.A.; Annable, P.; Phillips, G.O.; Nishinari, K. Mixed Polysaccharide Gels Formed between Xanthan Gum and Glucomannan. In Food Hydrocolloids: Structures, Properties, and Functions; Nishinari, K., Doi, E., Eds.; Springer: Boston, MA, USA, 1993; pp. 435-449. ISBN 978-1-4615-2486-1.

63. Xue, D.; Sethi, R. Viscoelastic Gels of Guar and Xanthan Gum Mixtures Provide Long-Term Stabilization of Iron Micro- and Nanoparticles. J. Nanopart. Res. 2012, 14, 1239. [CrossRef] 